\title{
Inscribed Pompeian millstones from Tarragona, Spain
}

\author{
Diana Gorostidi Pi, Jordi López Vilar \\ and Hernando Royo Plumed
}

\begin{abstract}
This paper presents a small assemblage of inscribed Pompeian millstones from Roman Tarraco and its surroundings (Tarragona, Spain). Pompeian millstones are not common in the Spanish Peninsula. Furthermore, most are long-distance imports from volcanic quarry districts elsewhere in the Mediterranean, notably the Vulsini sector near Orvieto (north of Rome) characterised by leucite crystals. Inscribed millstones are even less common in Hispania. The three cases presented in this paper (two catilli and one meta), with clear links to Italy, are the only known examples to date bearing inscriptions in Spain. This paper also establishes that inscription analyses, in conjunction with typological and petrological studies, can serve in resolving the complex process of millstone provenancing and dating.
\end{abstract}

Keywords: Tarragona, Pompeian mill, inscription, volcanic rock, leucite, millstone trade

Institut Català d’Arqueologia Clàssica, Pl. Rovellat, s/n, 43003 Tarragona, Spain, dgorostidi@icac.cat, jlopez@icac.cat,hroyo@icac.cat

\section{Introduction}

The aim of this article is to give wider dissemination to the three inscribed Roman Pompeian-style molae asinariae of volcanic stone discovered in or near the city of Tarraco (Tarragona). Although they have been previously published independently, a review of the earlier documentation and the comparison with counterparts in Italy offers a new perspective on these mills. These examples are of particular interest because there are relatively few inscribed models of this type outside the Italian Peninsula and they are the only inscribed examples known to date in the Iberian Peninsula.

The best preserved and best known of the three, currently on display in the National Archaeological Museum in Tarragona (MNAT), is an inscribed catillus that was originally published in the first edition of the Corpus Inscriptionum Latinarum (CIL II2, 6114) and cited in subsequent studies (CIL II2/14, 1892; Rodà, 2002, 37; Tarraco pedra a pedra 2009, 8; Anderson et al. 2016). However, these publications only refer to the mill's upper stone, whereas this study also presents for the first time the mill's inscribed lower stone (meta) preserved in a fragmented state in the museum's depository.

Unfortunately we were not unable to locate a second catillus from Tarraco that, according to 19th century inventories, is stored in the MNAT museum. Finally, this study also includes a third fragment of a catillus from the Ager Tarraconensis published recently (Gorostidi 2010, IRAT 55). It was discovered at the Roman villa of Els Antigons outside of Tarragona and bears an inscription with parallels in Italy. 


\section{The Pompeian mills from Tarragona}

\section{Mola asinaria (inv. 2505)}

Mill no. 2505 (Figs 1-4) was discovered during excavations in the Port of Tarragona on August 27, 1863. The day after the discovery the local press reported the circumstances of the find (Hernández Sanahuja, 1863, see Appendix 1). Its archaeological context was described as in situ under the charred remains (beams, bricks, earth) of a Roman house. The destruction layer described by the press was attributed to the violent Barbarian incursions during the time of Gallienus (middle of the 3rd century AD).

Archaeological work in recent years in Tarragona has also revealed numerous strata evidencing a widespread demolition. Finds of caches of coins in these levels have been interpreted as proof of a period of instability resulting from the Germanic razzias recorded by the written sources (López Vilar 2006, 240-42). The destruction levels are not only identified in the port and western suburb, but also inside Roman Tarragona's city walls. Therefore this mola asinaria dates almost certainly to 260-270 AD.

The complete mill (upper and lower stone) is estimated to have measured about $1.50 \mathrm{~m}$ in height. At the moment of its discovery, it was sketched in situ. Unfortunately, the original drawing, published years later (Guillén-García 1893), has since been lost. Furthermore, during its transfer to the museum, the meta broke into pieces. Only the catillus and the meta fragment with the inscription were saved and catalogued (Inventory Number 2505; see description

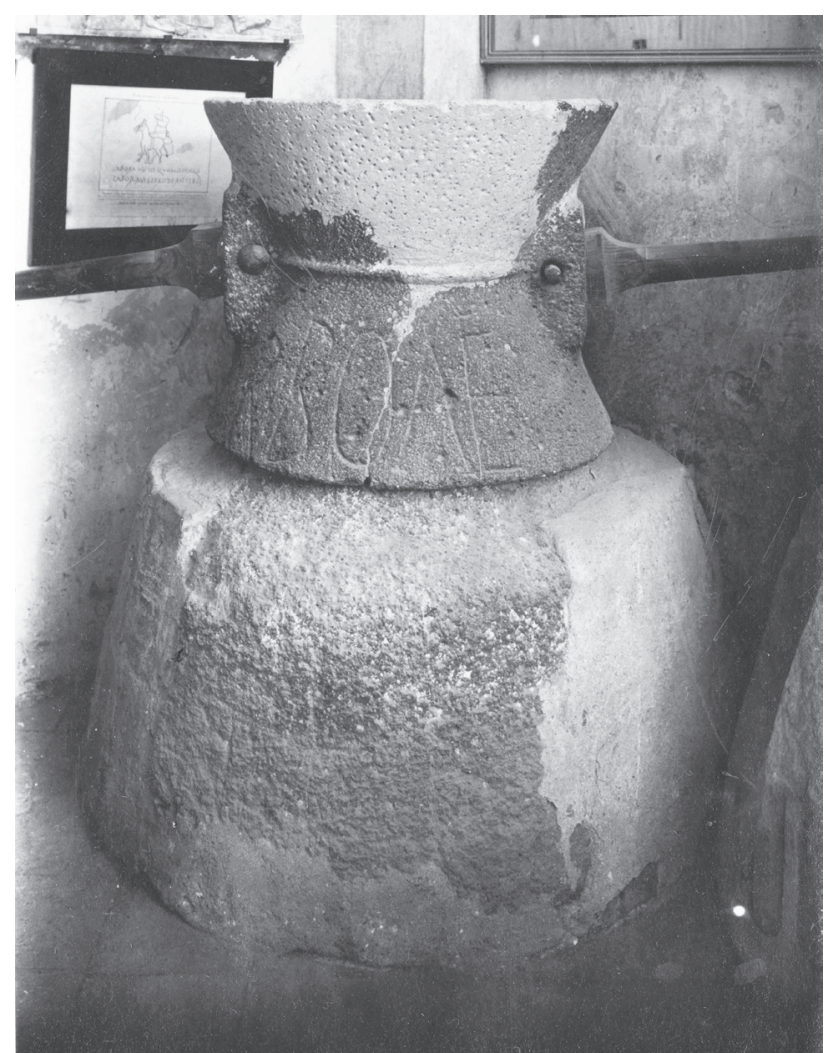

Fig. 1: Old photograph of the complete mola asinaria discovered in 1863 as it was exhibited in the Archaeological Museum of Tarragona (MNAT) in the early 20th century (photo by MNAT).

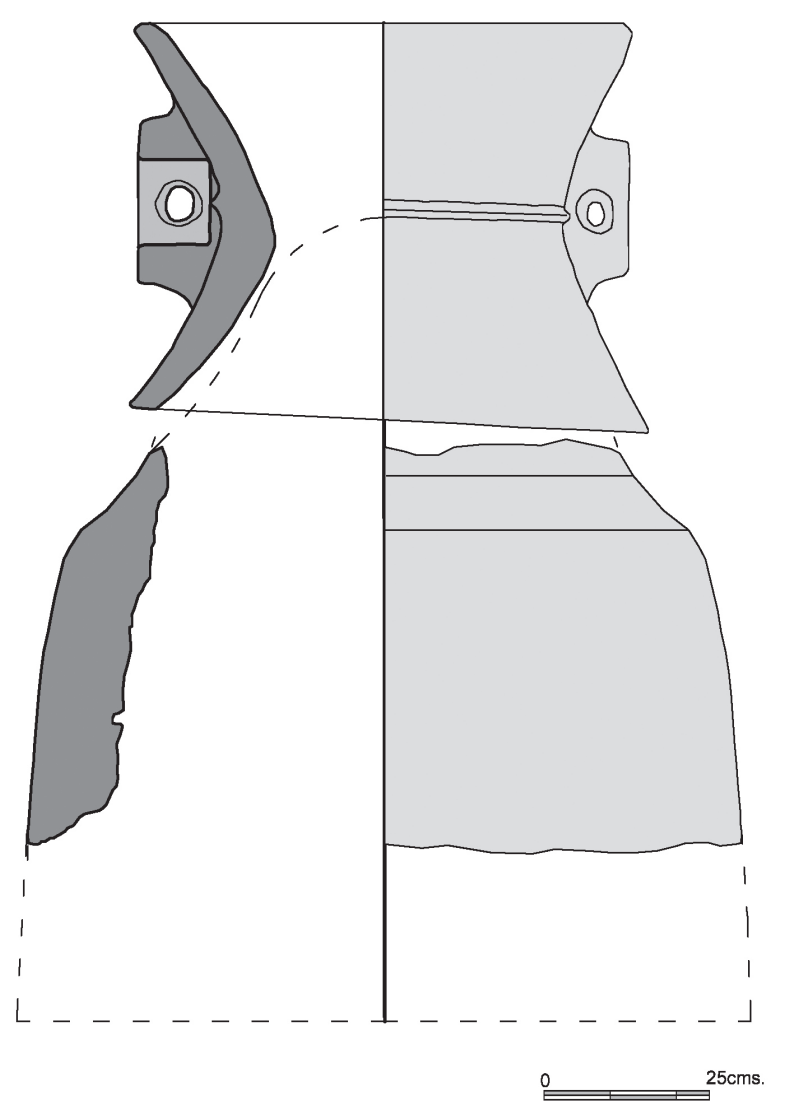

Fig. 2: Section of the complete mill (inv. 2505) (drawing by Paloma Aliende).

in Hernández and Del Arco 1894, 161; of note is the confusion as the date of the find, 1868 instead of 1863).

Of particular interest is the fact that the two stones are of different petrography leading us to wonder if they were originally a pair or not. The catillus is a grey volcanic rock, identified under a microscope as olivine basalt with pyroxene phenocrysts (maximum size of $5 \mathrm{~mm}$ ). It is highly vesicular (some vesicles as large as one centimetre). The meta, by contrast, is a light grey volcanic rock, corresponding presumably to a porphyritic pyroxene basalt with leucite phenocrysts (very abundant and heterometric, up to a centimetre in length).

The catillus, measuring $75 \mathrm{~cm}$ in diameter and between 57.5 and $62.5 \mathrm{~cm}$ in height, has prominent hoppers and opposite rectangular handle lugs at its midsection. These features place it as Type $3 \mathrm{~b}$ or 3c of Peacock's classification (1989). One of the surfaces bears the inscription RBOAETI carved in large letters, joined to the letters ETI (CIL II 6114 = RIT $\left.814=C I L \mathrm{II}^{2} / 14,1892\right)$.

Although there is no epigraphic parallel for RBOAETI, it has been interpreted as R(ota) Boaeti. Rota is thought to represent the mola itself ( $c f$. the rota figularis Latin meaning as a potter's wheel in Sen. Ep. 90, 31) and Boaetius (= Boethius, a name that is well documented in epigraphy, including its Boaet- form) as its manufacturer or owner ( $c f$. Rodà 2002, nr. 37; CIL II²/14, 1892). 


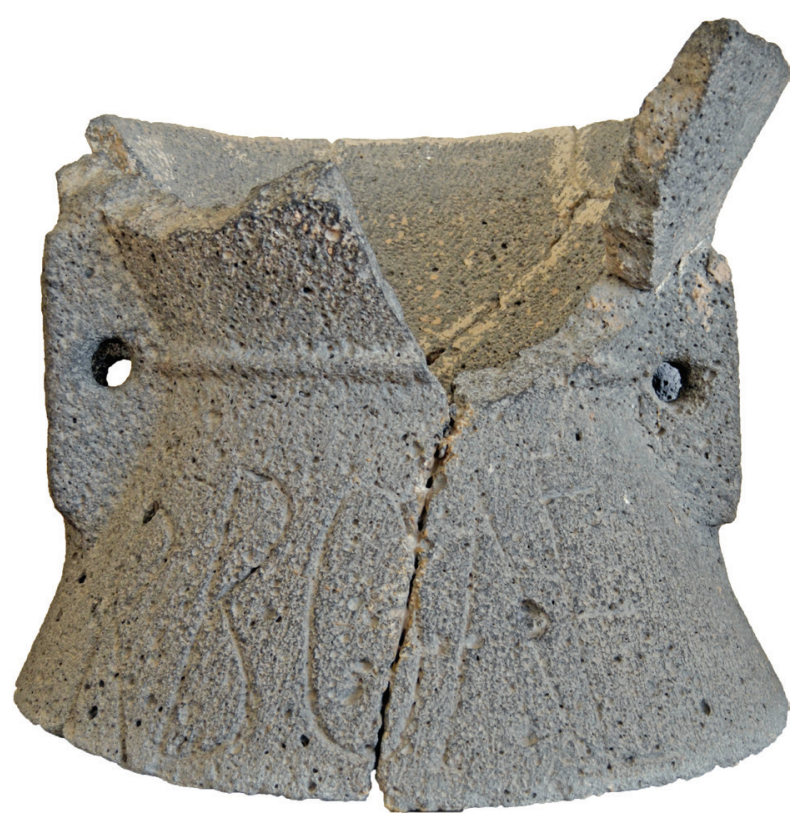

Fig. 3: Catillus in the current exhibited in the MNAT (inv. 2505) (photo by Hernando Royo).

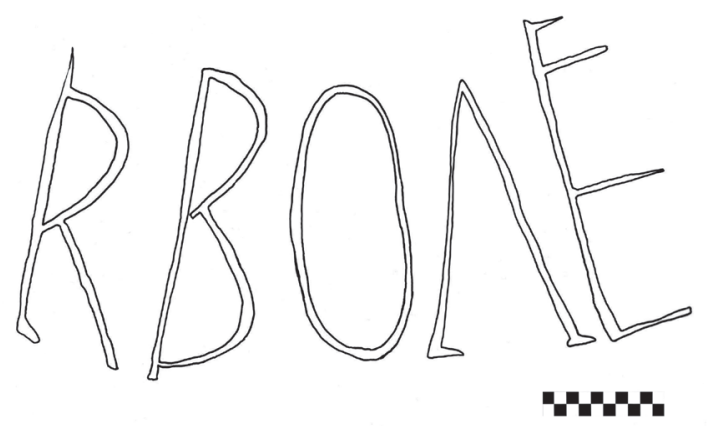

Fig. 4: Rubbing of the RBOAETI inscription on the 2505 catillus (drawing by Diana Gorostidi).

Its seven-letter inscription stands out as it is exceptionally long compared to others on Pompeian mills which usually only comprise three letters (e.g. SEX, HOS, CEA) with the exception of the mills of Ostia, studied by Bakker (1999), that have four or more adjoining letters (PAR, CHRY, SPCYR, GIAH), a fact that complicates their interpretation. No study of Ostian or Pompeian inscriptions has suggested anything other than that the letters correspond to manufacture markings (De Rossi 1857; Bakker 1999, 78). This large and long palaeographic type, approaches the epigraphic style of the Tarraconense catillus to the Ostia group (Fig. 5).

The meta is now in two poorly preserved fragments stored in the MNAT depository. The early photograph from the Museum reveals how it was reconstructed for display (cf. Fig. 1). But since it broke a second time, it is now in storage. The original publication notes that it was a cylinder capped by a bell and with a hollowed base. Its top had a square spindle socket $(8 \times 8 \mathrm{~cm})$. The inscription IEPE, carved in large letters, was toward the base. The loss of the fragment bearing these letters prevents confirming the reading. However, the description of the letters as 'large' suggests they were similar to those on the catillus. In fact, the marks inscribed on Pompeianstyle mills are characterised by their large letters and, often, by their cryptic nature, especially those from Ostia (cf. infra).

\section{A second catillus fragment (inv. 2506)}

A second catillus, similar but smaller than inv. no. 2505, was brought to light in 1857 and deposited in the Archaeological Museum (Hernández Sanahuja, 1863). It corresponds to half an upper stone of the same type as that described above. According to Hernández and Del Arco $(1894,161)$, it was catalogued as number 2506. Unfortunately, a search of the museum collection has failed to locate it and we therefore do not know if it was inscribed or not.

\section{$A$ catillus from the Roman villa of Els Antigons (Reus, Tarragona)}

A third catillus fragment with an inscription was found at the Roman villa of Els Antigons (Figs 6-8), 6.5 kilometres to the east of Tarraco. It is now in the Salvador Vilaseca Museum of Archaeology in Reus (inv. IMMR 20 09). The settlement of Els Antigons was occupied between the 2nd century BC and the 6th-7th centuries AD (Járrega and Prevosti 2014). Since this is a surface find, the stone is devoid of stratigraphic context.

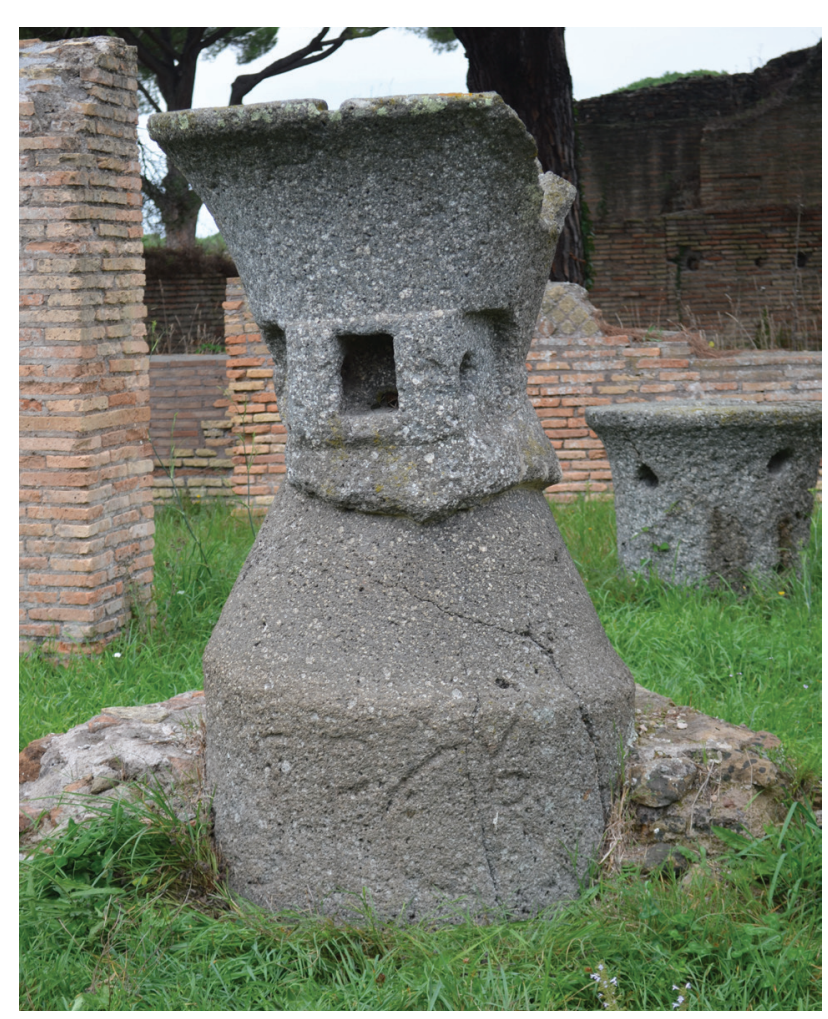

Fig. 5: Millstone in Ostia, Italy (Molino I, XIII, 4) with the SPCYR inscription on the meta (photo by Hernando Royo). 


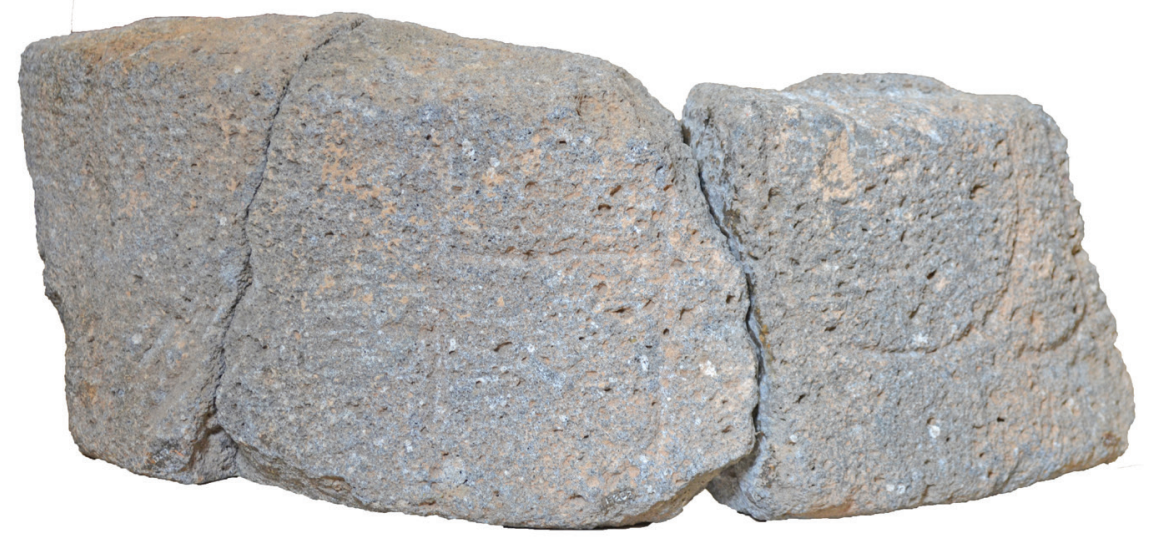

Fig. 6: Fragment of a catillus from the settlement of Els Antigons (photo by Hernando Royo).

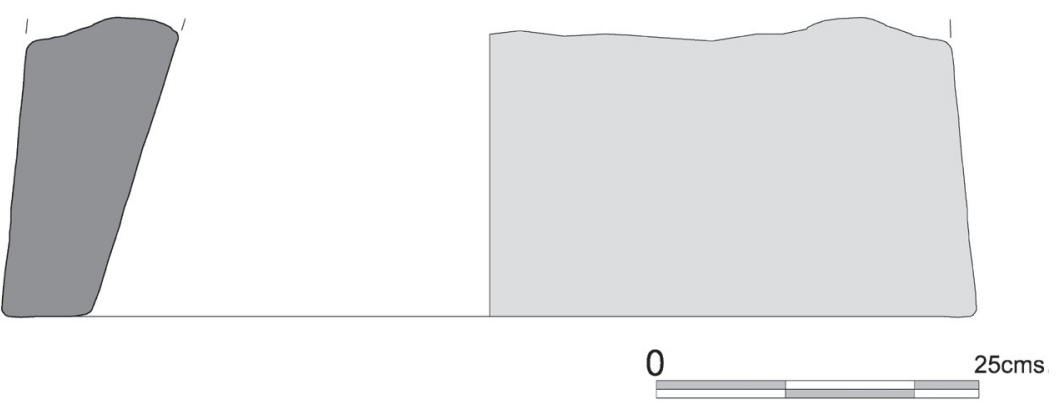

Fig. 7: Section of the catillus of Els Antigons (inv. IMMR 20 09) (drawing by Paloma Aliende).

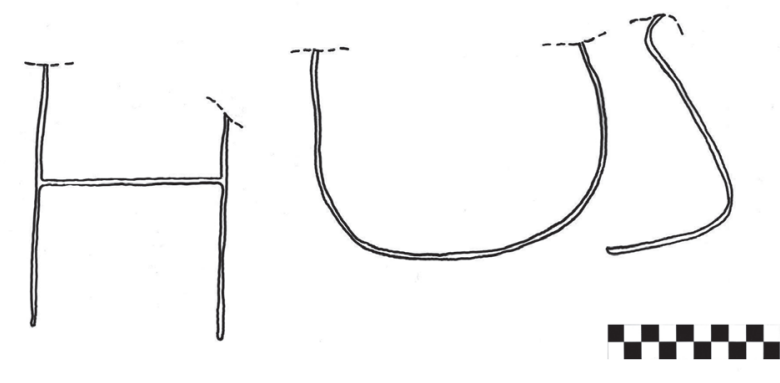

Fig. 8: Rubbing of the HOS inscription on the Els Antigons fragment (by Diana Gorostidi).

Its diameter is about $75 \mathrm{~cm}$ (height unknown). It was hewn from a light grey volcanic rock identified macroscopically as basalt with phenocrystals of leucite and millimetre-sized pyroxene (common among the millstones of Pompeii).

Despite not preserving any other characteristic features, its estimated diameter allows us classify it as a Peacock Type 3. This hypothesis is backed up by its inscription HOS (IRAT $55=C I L \mathrm{II}^{2} / 14$, 2263 ) that was initially identified as SOH (Gorostidi
2015). It has various parallels in Italy, especially at Pompeii (three examples) and Stabiae (Fig. 9), as well as outside Campania in Cora and Preneste (CIL X 8057, 7). This indicates a clear terminus ante quem of $79 \mathrm{AD}$. Furthermore, several millstones bearing the HOS inscription also correspond to Peacock Type 3.

\section{Discussion and conclusions}

It is reasonable to draw the following archaeological, historical and epigraphical conclusions. Firstly, with respect to petrology (Fig. 10), the porphyric basalt with leucite phenocrystals of the meta from Tarragona and the catillus from Els Antigons is characteristic and easy to identify macroscopically. Despite the lack of chemical analyses, it is possible to link these two millstones to the quarries in the area of Orvieto in the Vulsini volcanic district north of Rome by means of the findings of the analyses carried out both in Italy (Peacock 1986; Buffone et al. 2003; Santi et al. 2003; Antonelli and Lazarini 2010) and in the south of France (Jaccottey and Longepierre, 2011, 109-12).

Furthermore, the typology of some of the Tarraco millstones and their inscriptions serve to connect 


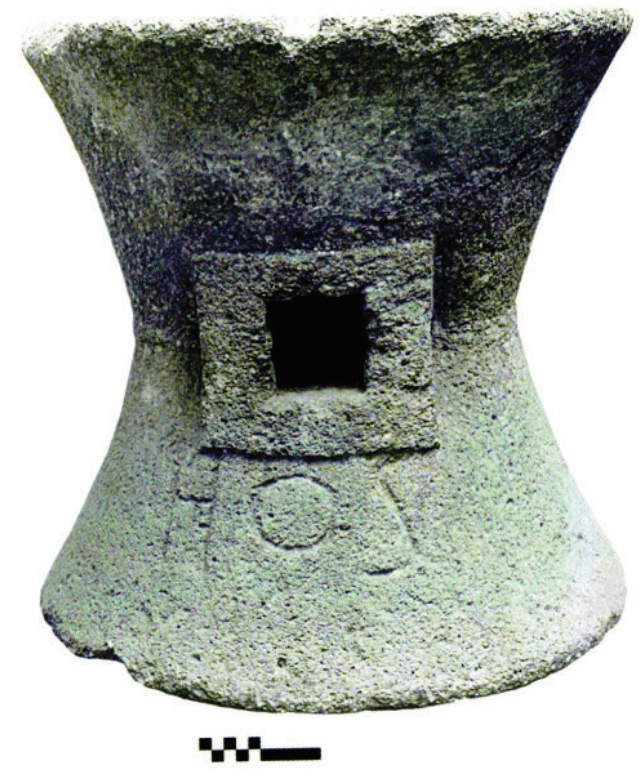

Fig. 9: HOS inscription on a catillus from Stabiae, Italy (from Magalhães, 2006).

them to the mills of Pompeii and Ostia, assemblages that are generally considered to have been procured in the Orvieto quarries.

The Tarragona catillus (inv. 2505), by contrast, was hewn from a grey volcanic rock devoid of leucite macrocrystals. The specific origin of this rock type is difficult to pinpoint as it could have been quarried in a number of different volcanic districts spread throughout the Mediterranean Basin (Williams-Thorpe 1988).

Secondly, of the dozen molae asinariae identified to date in Hispania (Anderson et al. 2016), three are from Tarraco and its surroundings. It is noteworthy that these examples are the only cases bearing inscriptions. This suggests a maritime link between Tarraco and the ports of the Tyrrhenian, Latian or Campanian coasts. This link is corroborated both by the rock type, notably leucite lava, and the presence of identical inscriptions such as the HOS inscription identified at Pompeii on the catillus of Els Antigons. However, the low number in Iberia suggests imports of molae asinariae from Italy through the port of Tarraco were sporadic.

Also worth noting are two anepigraphic leucite lava catilli surface finds associated with the Roman villa of Las Coronas (Lanaja, Huesca, Zaragoza) (Mínguez and Ferreruela 1992, 134-135; Anderson et al. 2016). The source of these imports found about $140 \mathrm{~km}$ inland from Tarraco, is also most likely the area of Orvieto north of Rome. It is feasible to speculate that the two catilli transited through the Tarraco port before being ferried to Las Coronas over the Ebro River.

Thirdly, the presence of at least two catilli in the residential quarters of Tarraco provides indirect evidence of industrial urban bakeries. Furthermore, it can be assumed that the Roman Villa of Els
Antigons had a pistrinum and produced a large supply of flour for its dependents during, at least, the Flavian period.

Fourthly, the HOS inscription suggests a similar chronology for all of the catilli bearing this inscription: six in Italy and the single case of Els Antigons. In the publication of the Stabiae millstone, this inscription was interpreted as Hostius (?) and linked to the manufacturer of the millstone. It is also possible to speculate that there is a bond with a similar name found on certain tegulae dated to the period of Tiberius (Magalhães 2006, 67, 173). Thus the Hos(tii) inscription suggests a dating for this mill assemblage at the very end of the Flavian period (i.e. turn of the 1 st century AD).
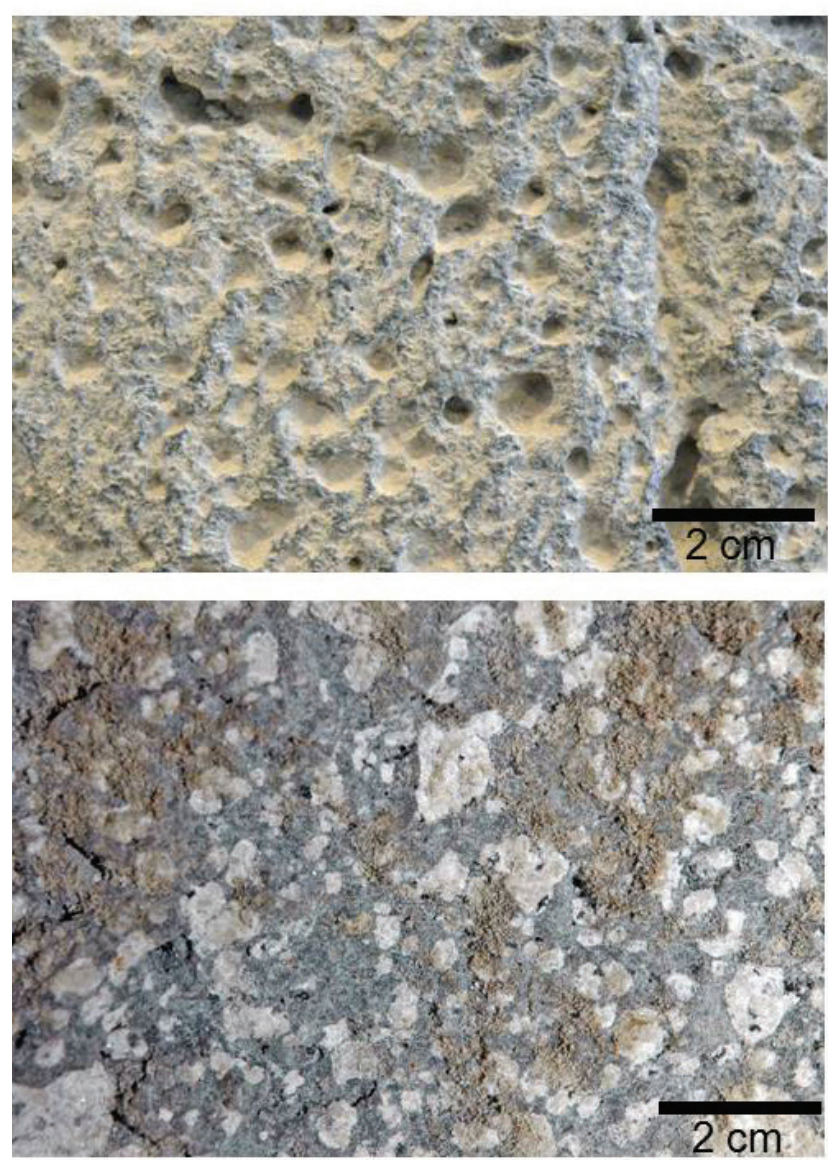

Fig. 10: Details of petrography of the Tarragona volcanic millstones. From left to right, catillus $1 \mathrm{~b}$ and meta $1 \mathrm{a}$ (inv.

2505) and Els Antigons catillus (Inv. No. IMMR 20 09) (photo: Hernando Royo). 
Hence inscriptions, apart from their intrinsic information, can also serve as indicators, along with typology and petrology, of dating. The Els Antigons stone, for example, is dated to the second half of the 1st century AD based on parallels at Pompeii bearing the same letters (HOS). In the case of the mill from the Tarraco port, parallels are also identified in the port of Ostia. Indeed, the inscriptions on the Ostian mills are generally longer than those from Pompeii. In addition, the inscriptions on the metae do not normally coincide with those of their respective catilli, as is also the case in Tarragona, where the catillus inscribed with RBOAETI was discovered together with a meta bearing the IEPE inscription. It is therefore possible that one of the stones was broken and replaced by another manufactured in a different workshop.

The inscribed Ostian mills are associated with bakeries operatimg between the 2nd and 5th centuries (Molino I, XIII, 4, cf. Bakker 1999, 16-33) or in the 3rd century AD (Caseggiato dei Molini I, III, 1), dates that are, in any case, later than the Flavian chronology of the Campanian examples. In keeping with the later dating of the mills from Ostia, the Tarraco catillus, with a morphology and inscription different from than that of Els Antigons, can probably be placed in the mid-Imperial period (3rd century AD), coinciding perfectly with the date of the layer of destruction identified during the different excavations of Tarraco.

\section{Acknowledgements}

This study is part of a research project $\mathrm{La}$ explotación y comercio de los recursos naturales al Norte de la Hispania romana: lapis, metalla, aqua (HAR2011-25011). We would like to express our gratitude for the support and facilities offered by Jaume Massó (Museu d'Arqueologia Salvador Vilaseca de Reus), Josep Anton Remolà (Museu Nacional Arqueològic de Tarragona) and Paloma Aliende (Institut Català d'Arqueologia Clàssica). We also thank Timothy Anderson for his suggestions for the text and Luc Jaccottey for the exchange of ideas.

\section{Bibliography}

Anderson, T., Jaccottey, L., Cambeses, A., And Scarrow, J.H., 2016. Premier bilan sur les moulins pompéiens dans la péninsule ibérique. In: L. Jaccottey and G. Rollier (eds), Archéologie des moulins hydrauliques, à traction animale et à vent, des origines à l'époque médiévale. Lons-le-Saunier, Colloque 2-6 novembre 2011, Volume 2, Besançon, 619-32.

Antoneli, F. And Lazzarini, L., 2010. Mediterranean trade of the most widespread Roman volcanic millstones from Italy and petrochemical markers of their raw materials, Journal of Archaeological Science, 37, 2081-92.

BAKKeR, J.T., 1999. The Mills-bakeries of Ostia: description and interpretation. Amsterdam.

Buffone, L., Lorenzoni, S., Pallara, M. And Zanettin, E., 2003. The Millstones of ancient Pompeii: a petro-archaeometric study, European Journal of Mineralogy, 15, 207-15.

\section{$C I L=$ Corpus Inscriptionum Latinarum.}

CIL $\mathrm{II}^{2} / 14$ = Corpus Inscriptionum Latinarum. Vol. II. Inscriptiones Hispaniae Latinae. Editio Altera. Pars XIV. Conventus Tarraconensis.

De Rossi, G.B., 1857. Antichi mulini in Roma en el Lazio, Annali dell'Istituto di Corrispondenza Archeologica di Roma, 1857, 274-81.

GoRostidI, D., 2015. "Epigrafía “menor" del ager Tarraconensis (Hispania Citerior): Novedades del Camp de Tarragona”, In: M. Scholz And M. HoRster (eds), Lesen und Schreiben in den römischen Provinzen, Schriftliche Kommunikation im Alltagsleben. Akten des 2. Internationalen Kolloquiums von DUCTUSAssociation Internationale pur l'étude des inscriptions mineures (Mainz, del 15 al 17 de juny de 2011), Verlag des Römisch-Germanischen Zentralmuseum, Band 26, Mainz, 205-18.

Guillén-García, G.J., 1893. Molas. Visitas a los museos arqueológicos de Tarragona, de Gerona y otros, Boletín de la Asociación Artístico-Arqueológica Barcelonesa, III.2, 370-73. 2-1893.

Hernández Sanahuja, B., 1863. Antigüedades, Diario de Tarragona, X.239. 28-8-1863.

IRAT = Gorostidi, D., 2010. Ager Tarraconensis 3. Les inscripcions romanes. Documenta, 16. Tarragona.

Hernández Sanahuja, B. And Del Arco, A., 1894. Catálogo del Museo Arqueológico de Tarragona. Tarragona.

Jaccottey, L. And Longepierre S., 2011. Pompeian millstones in France. In: D. Williams and D. Peacock (dir.). Bread for the people: The Archaeology of Mills and Milling : proceedings of a colloquium held in the 
British School at Rome, 2009, (International Series $B A R$; 2274), University of Southampton, 97-116.

Járrega, R. And Prevosti, M. (eds), 2014. Ager Tarraconensis 4. Els Antigons, una vil.la senyorial del Camp de Tarragona. Documenta, 16. Tarragona.

LóPez VILAR, J., 2006. Les basíliques paleocristianes del suburbi occidental de Tarraco. El temple septentrional i el complex martirial de Sant Fructuós, Documenta, 4. Tarragona.

Magalhães, M.M., 2006. Stabiae romana: la prosopografia e la documentazione epigrafica: iscrizioni lapidarie e bronzee, bolli laterizi e sigilli. Castellammare di Stabia.

Minguez Morales, J.A. And Ferreruela Gonzalvo, A., 1992. La villa romana de las Coronas (Pallaruelo de Monegros, Huesca), Bolskan, 9, 133-58.

Peacock, D.P.S., 1986. The Productions of Roman Millstones Near Orvieto, Umbria, Itay, The Antiquaries Journal, 66.1, 45-51.
Peacock, D.P.S., 1989. The mills of Pompeii, Antiquity, 63.239, 205-14.

RIT = AlFöldy, G., 1975. Die Römischen Inschriften von Tarraco, Berlin.

Tarraco pedra a pedra, 2009. Tarraco, pedra a pedra. Catàleg de l'exposició (Tarragona, 10 de juny al 22 de novembre de 2009), Tarragona.

RodÀ, I., 2002. Un recorregut per l'exposició Scripta Manent. In: R. Comes AND I. RodÀ (eds), Scripta manent: La memòria escrita dels romans. Barcelona, 26-51.

Santi, P., Antonelli, F., Renuzulli, A. And Pensabene, P., 2003. Leucite phonolite millstones from the Orvieto production centre: new data and insights into the Roman trade, Periodico di Mineralogia, 73, 57-69.

Williams-Thorpe, O., 1988. Provenancing and Archaeology of Roman Millstones from the Mediterranean Area, Journal of Archaeological Science, 15, 253-305. 


\section{Appendix}

\section{Article from the newspaper Diario de Tarragona, 1863.}

Antigüedades, Diario de Tarragona, año X, núm. 239, 28-08-1863.

Ayer en las excavaciones de la cantera del puerto de esta ciudad, dentro de una habitación romana arruinada, y cubierto de vigas carbonizadas, ladrillos, piedras calcinadas, tierra y ceniza apareció un resto, cuyo uso y objeto no ha podido adivinarse. Era pues, un cilindro de 80 centímetros de diámetro y un metro de altura, formado de una composición o pasta que tenía todo el aspecto del granito ceniciento. Encima de esta base había un cono acampanado, que a primera vista parecía el molde interior de una gran campana.

Este resto de una sola pieza, estaba vacio y sentado sobre un lecho de piedras, y en la parte inferior del cilindro se hallaban esculpidas en grandes dimensiones estas letras IEPE. Alrededor del cono descansaba otra gran pieza a modo de collarino, construida de una piedra esponjosa semejante a la piedra pómez pero de color negruzco, de una dureza y peso extraordinarios, adornada de dos grandes asas de una figura particular; alrededor de esta pieza hay esculpidas las letras RBOAE. La forma de estas letras revela desde luego que el resto se construyó durante el período de la decadencia del imperio, y lo confirma la ruina que lo cubría perteneciente a la época de la entrada de los bárbaros en tiempo de Galieno. La violencia del fuego, causa de la ruina del edificio calcinó el cilindro de

\section{Abridged translation by the editor}

"An uncommon find appeared yesterday during excavations at the port of this city inside a destroyed Roman house covered with charred beams, bricks, stones, earth and ashes. It is a rock cylinder 80 centimetres in diameter and one meter high made of what appears to be ashen granite [error, the rock is volcanic]. The cylindrical base was mounted by a bell-shaped cone, which at first glance appeared to be the mould of a large bell.

The lower piece, in one piece, was hollowed and rested on a bed of stones. Along its base the inscription IEPE was carved in large letters. Around the cone was another large stone object resembling the collar of a capital made of a spongy blackish pumice that is extraordinary hard and heavy. It is adorned with two large strange handles and inscribed with the letters RBOAE. The shape of these letters reveals, of course, that it was built during the period of the decline of the Empire. Its position, covered by the ruins of the house confirms that it belonged to the arrival of the barbarians during the time of Gallienus. The violence of the fire, the cause of the collapse of the building, calcined the cylinder tal modo, que a pesar del exquisito cuidado y de las precauciones tomadas por el Sr. Rebolledo, director de las obras del puerto, y del ayudante de las mismas D. Pablo Bartroli para sacarlo entero, al levantarlo en peso del suelo se agrietó, rompiéndose en mil piezas, afortunadamente se consiguió salvar entera la inscripción del cilindro y todo el collarino que rodeaba el cono, que inmediatamente hizo conducir al museo arqueológico el Sr. Hernández inspector de antigüedades.

Cuando completo este resto tenía un metro 80 centimetros de altura, y su aspecto ofrecía alguna semejanza con nuestros molinos de chocolate; y no sería un despropósito pensar que realmente fuese algún molino para cereales, de aquella época; parece confirmarlo la circunstancia de haber encontrado en el vértice del cono al romperse un dado de plomo de ocho centímetros cúbicos.

Antes de moverlo de su lugar se tuvo la precaución de sacar un dibujo de este resto a fin de poder ser estudiado y aplicando a las artes de los antiguos. Hace seis años que en la misma cantera apareció otro collarino igual, en forma, materia y color, que el citado inspector hizo trasladar al museo, en donde existe.

[Bonaventura Hernández Sanahuja] to such an extent that despite the great care and precautions taken by Mr. Rebolledo, director of the port works, and his assistant D. Pablo Bartrolí to remove it whole, it cracked under its own weight and broke into a thousand pieces. Fortunately they managed to save the entire inscription cylinder and the rim of the cone. Mr. Hernandez, the inspector of antiquities, had the objects immediately taken to the archaeological museum.

When mounted the feature measured one meter and 80 centimetres in height and it resembles some of our chocolate mills. It would not be misguided to think that it was really was a Roman grain mill. A sort of lead dice measuring eight cubic centimetres was found at the apex of the cone."

Before moving the object we took the precaution of photographing it for study and applied to the arts of the ancients had. Six years ago was found another stone collar-shaped object similar in shape, rock type and colour to this example. It was moved to the museum by the inspector." 